\title{
PENGARUH KOMITMEN PROFESIONAL, KOMITMEN ORGANISASIONAL, DAN BUDAYA ORGANISASI TERHADAP KEPUASAN KERJA AKUNTAN PENDIDIK, STUDI KASUS PADA UNIVERSITAS DI YOGYAKARTA
}

\author{
Yuni Wulandari \\ Sumaryanto
}

\begin{abstract}
Abstrack
The purpose of this research examines for the influences of professional commitment, organizational commitment, and organization culture to the satisfaction of work. The population of this research are the educationalist accountants (the lecturers who have an accountant professional's degree) from some of universities in Yogyakarta. This research takes samples by using quizioner. The technique of sample's taking use purposive sampling for the population that has been chosen with responden's requirement based on those requirement, there are 45 respondents as the sample from 7 universitas in Yogyakarta. Based on the result of analysis, it could be cocluded that the professional commitment and organizational commitment do not give influence to the work;s satisfaction of educatinalist accountants. Otherwise, the organization culture give influence to the work's satisfaction of educationalist accountants.
\end{abstract}

Keyword: Professional commitment, organizational commitments, organization culture and the work's satisfaction of educationalist accountant.

\section{PENDAHULUAN}

Penelitian mengenai komitmen, budaya dan kepuasan kerja merupakan topik yang menarik untuk diteliti lebih lanjut, karena masalah kepuasan kerja akan terus menerus muncul dalam suatu organisasi, serta masih ditemukannya perbedaan antara beberapa hasil penelitian terdahulu, sehingga dimungkinkan untuk dilakukan penelitian lebih lanjut, terutama dalam bidang akuntansi keperilakuan. Pemenuhan kebutuhan hidup manusia dapat dilakukan dengan cara bekerja dengan tujuan untuk memperoleh penghasilan. Seseorang dikatakan mempunyai kepuasan kerja ketika pekerjaan yang ditekuninya memberikan rasa puas baik dari segi material maupun non material.

Keberhasilan dan kinerja seseorang dalam suatu bidang pekerjaan banyak ditentukan oleh tingkat kompetensi, profesionalisme, dan komitmennya terhadap bidang yang ditekuninya. Bidang pekerjaan yang membutuhkan tingkat keahlian dan independensi tertentu seperti pada profesi akuntan, pada dasarnya diperlukan beberapa jenis komitmen seperti komitmen organisasional dan komitmen 
profesional. Suatu komitmen organisasional menunjukkan suatu daya dari seseorang dalam mengidentifikasi keterlibatannya dalam suatu bagian organisasi (Mowday, Porter, \& Steers, 1982 dalam Trisnaningsih dan Didik., 2002).

Selain komitmen organisasional, adanya orientasi profesional yang mendasari timbulnya komitmen profesional nampaknya juga akan berpengaruh terhadap kepuasan kerja. Para professional merasa lebih senang mengasosiasikan diri mereka dengan organisasi profesinya dalam melaksanakan tugas, dan mereka mempunyai keinginan lebih besar untuk menaati norma, aturan dan kode etik profesi dalam memecahkan masalah-masalah yang mereka hadapi. Dengan demikian, komitmen baik secara langsung ataupun tidak tentunya akan berpengaruh pada kepuasan kerja seseorang (Copur, 1990 dalam Trisnaningsih dan Didik, 2002).

Budaya organisasi dapat mempengaruhi cara orang dalam berperilaku dan harus menjadi patokan dalam setiap program pengembangan organisasi dan kebijakan yang diambil. Hal ini terkait dengan budaya yang mempengaruhi organisasi dan pengelolaan budaya tersebut oleh organisasi. Budaya organisasi itu berkaitan dengan cara karyawan mempersepsikan karakteristik budaya organisasi, bukannya dengan apakah mereka menyukai budaya itu atau tidak (Robbins, 2006).

Peranan dari karyawan sangat signifikan terhadap semua perubahan yang dilakukan oleh organisasi di tempat kerja, karena karyawan juga sebagai salah satu motor penggerak utama dari organisasi untuk bisa memenuhi target dan tujuan dari organisasi atau perusahaan yang dinaunginya tersebut. Karyawan terkait dengan timbulnya kepuasan kerja yang dimiliki oleh mereka. Apabila karyawan dapat bekerja keras maka akan membawa pada satu titik pengertian yaitu kepuasan kerja.

Akuntan (accountant) adalah gelar bagi mereka yang telah lulus ujian akuntansi seperti yang telah ditetapkan dalam Undang-Undang Nomor 34 Tahun 1954. Tenaga akuntansi secara umum dapat didefinisikan sebagai mereka yang memiliki pengetahuan di bidang Akuntansi. Undang-undang Nomor 34 Tahun 1954 berisi: "Dengan tidak mengurangi ketentuan dalam peraturan gaji resmi mengenai berbagai jabatan pada Jabatan Akuntan Negeri dan Jabatan Akuntan Pajak, hak memakai gelar "akuntan" ("accountant") dengan penjelasan atau tambahan maupun tidak, hanya diberikan kepada mereka yang mempunyai ijazah akuntan sesuai dengan ketentuan dan berdasarkan undang-undang ini. 
Berdasar latar belakang permasalahan yang telah dikemukakan, maka peneliti tertarik untuk menganalisis kembali pengaruh komitmen profesional, komitmen organisasional, dan budaya organisasi terhadap kepuasan kerja akuntan pendidik, sesuai dengan penelitian yang dilakukan oleh (Restuningdiah, 2009). Perbedaan penelitian ini dengan penelitian sebelumnya adalah pada objek penelitian. Penelitian terdahulu menggunakan akuntan pendidik di Jawa Timur sebagai responden, sedangkan penelitian ini menggunakan akuntan pendidik di Yogyakarta sebagai responden. Perbedaan lain penelitian ini dengan penelitian dahulu yaitu penelitian ini menambahkan variabel yaitu budaya organisasi. Berdasarkan uraian tersebut, maka peneliti tertarik untuk meneliti pengaruh komitmen profesional, komitmen organisasional dan budaya organisasi terhadap kepuasan kerja akuntan pendidik, studi kasus pada universitas di Yogyakarta.

\section{TINJAUAN PUSTAKA}

\section{Akuntan Pendidik}

Akuntan (accountant) adalah gelar bagi mereka yang telah lulus ujian akuntansi seperti yang telah ditetapkan dalam Undang-Undang Nomor 34 Tahun 1954. Tenaga akuntansi secara umum dapat didefinisikan sebagai mereka yang memiliki pengetahuan di bidang Akuntansi.

Akuntan pendidik yaitu akuntan yang bekerja sebagai pendidik, terutama bertugas dalam pendidikan akuntansi, yakni mengajar, menyusun kurikulum pendidikan akuntansi dan melakukan penelitian akuntansi. Akuntan pendidik juga sering dikatakan sebagai profesi akuntan yang memberikan jasa berupa pelayanan pendidikan akuntansi kepada masyarakat melalui lembaga-lembaga pendidik yang ada, guna melahirkan akuntan-akuntan yang terampil dan professional. Profesi akuntansi pendidik sangat di butuhkan bagi kemajuan profesi akuntansi itu sendiri, karena di tangan mereka para calon-calon akuntan pendidik. Akuntan pendidik harus dapat melakukan transfer knowledge kepada mahasiswanya, memiliki tingkat yang tinggi dan menguasai pengetahuan bisnis dan akuntansi, teknologi informasi dan mampu mengembangkan pengetahuanya melalui pendidikan. 


\section{Kepuasan Kerja}

Kepuasan atau job satisfaction adalah suatu sikap seseorang terhadap pekerjaan sebagai perbedaan antara banyaknya ganjaran yang diterima pekerjaan dan banyaknya yang seharusnya diterima pekerja. Kepuasan kerja di sini bisa dipengaruhi oleh hal yang dapat menyenangkan dari diri seseorang, apabila saat bekerja karyawan tidak memiliki perasaan senang, atau sedang terjadi masalah pada dirinya, maka saat bekerja ia tidak akan mendapatkan kepuasan kerja yang diharapkan. Apabila kepuasan kerja tidak terpenuhi maka semua pekerjaan yang dilakukan tidak akan mendapatkan hasil yang baik, justru cenderung asal-asalan. Kepuasan kerja adalah suatu perasaan positif tentang pekerjaan seseorang yang merupakan hasil dari sebuah evaluasi karakteristiknya. Seseorang dengan tingkat kepuasan kerja yang tinggi memiliki perasaan-perasaan positif tentang pekerjaan tersebut (Robbins, 1996 dalam Didit, 2013).

\section{Komitmen Profesional}

Komitmen profesional adalah tingkat loyalitas individu pada profesinya seperti yang dipersepsikan oleh individu tersebut (Larkin, 1990; Wibowo, 1996; dalam Trinaningsih, 2002), mengungkapkan bahwa tidak ada hubungan antara pengalaman internal auditor dengan komitmen profesional, lama bekerja hanya mempengaruhi pandangan profesionalisme, hubungan dengan sesama profesi, keyakinan terhadap peraturan profesi dan pengabdian pada profesi. Hal ini disebabkan karena semenjak awal tenaga profesional telah dididik untuk menjalankan tugas-tugas yang kompleks secara independen dan memecahkan permasalahan yang timbul dalam pelaksanaan tugas-tugas dengan menggunakan keahlian dan dedikasi mereka secara professional.

Robbin (1998) menyatakan komitmen merupakan suatu orientasi sikap individu terhadap nilai-nilai dan organisasi kerja. Wujud orientasi sikap berupa kemampuan identifikasi kondisi organisasi, kemampuan terlibat aktif, dimilikinya rasa setia, dan kepemilikan terhadap organisasi. Komitmen profesional yang didasari oleh pemahaman perilaku, sikap dan orientasi profesional seseorang dalam melaksanakan tugas-tugas merupakan cerminan dari norma-norma, aturan dan kode etik profesinya. 


\section{Komitmen Organisasional}

Komitmen organisasional didefinisikan sebagai suatu keadaan dimana seseorang karyawan memihak organisasi tertentu serta tujuan-tujuan dan keinginanya untuk mempertahankan keanggotaan dalam organisasi tersebut. Jadi, keterlibatan pekerjaan yang tinggi berarti memihak pada pekerjaan tertentu seorang individu, sementara komitmen organisasional yang tinggi berarti memihak organisasi yang merekrut organisasi tersebut (Robbins, 2008).

Perilaku komitmen organisasional menurut Luthans et al. (2005), ditentukan oleh nilai pribadi (usia, lama kerja, perangai atau sifat seperti pengaruh positif atau negatif, sifat pengendalian eksternal atau internal) dan organisasional (desain pekerjaan, gaya kepemimpinan seorang supervisor). Meskipun faktor lain seperti ketersediaan alternatif setelah keputusan telah dibuat untuk bergabung dengan organisasi akan berakibat pada komitmen lebih lanjut.

\section{Budaya Organisasi}

Budaya organisasi memilki makna yang luas. Menurut Luthans (2003: 108), budaya organisasi merupakan norma-norma dan nilai-nilai organisasi akan berperilaku sesuai dengan budaya yang berlaku agar diterima oleh lingkungannya, serta budaya organisasi dapat dipandang sebagai sebuah sistem. Menurut Andrew Pettigrew dalam Achmad Sobirin (2009) orang pertama yang secara formal menggunakan istilah budaya organisasi sebagai "the system of such publicly and collectively accepted meanings operating for given group at a given time-budaya adalah sistem makna yang diterima secara terbuka dan kolektif, yang berlaku untuk waktu tertentu bagi sekelompok orang tertentu".

\section{Pengaruh Komitmen Profesional Terhadap Kepuasan Kerja.}

Profesionalisme merupakan suatu atribut individual yang penting tanpa melihat suatu pekerjaan merupakan suatu profesi atau tidak. Sebagai professional, akuntan pendidik mengakui tanggung jawabnya terhadap masyarakat, terhadap klien, dan terhadap rekan seprofesi, termasuk untuk berperilaku yang terhormat, sekalipun ini merupakan pengorbanan pribadi. Sedangkan kepuasan kerja adalah suatu sikap umum terhadap pekerjaan seseorang sebagai perbedaan antara banyaknya yang 
diyakini dengan seharusnya diterima (Robbins, 2008). Semakin tinggi profesionalisme, maka semakin tinggi pula kepuasan kerja akuntan. Untuk itu dirumuskan hipotesis sebagai berikut:

H1: Komitmen profesional berpengaruh terhadap kepuasan kerja akuntan pendidik.

\section{Pengaruh Komitmen Organisasional Terhadap Kepuasan Kerja.}

Komitmen organisasional dan kepuasan kerja adalah dua hal yang sering dijadikan pertimbangan saat mengkaji pergantian akuntan yang bekerja (Poznanski dan Bline, 1997 dalam Restuningdiah dan Didit, 2013), agar tercipta komitmen organisasi yang tinggi di kalangan akuntan, maka dibutuhkan suatu rasa kepuasan kerja dari akuntan pendidik tersebut. Beberapa penelitian terdahulu, misalnya Gregson (1992) melaporkan hasil penelitiannya bahwa kepuasan kerja sebagai pertanda awal terhadap komitmen organisasional dalam sebuah model pergantian akuntan yang bekerja, namun terdapat batasan dalam penelitian tersebut, karena masalah identifikasi sebuah model dengan hubungan timbal balik antara kepuasan kerja dengan komitmen organisasional tidak dapat diuji. Penemuan hasil yang tidak konsisten dengan penelitian sebelumnya yaitu kepuasan kerja berpengaruh terhadap komitmen organisasional. Maka berdasarkan hal tersebut, hipotesis yang diajukan adalah :

H2: Komitmen organisasional berpengaruh tehadap kepuasan kerja Akuntan Pendidik.

\section{Pengaruh Budaya Organisasi Terhadap Kepuasaan Kerja.}

Budaya organisasi dapat mempengaruhi cara orang dalam berperilaku dan harus menjadi patokan dalam setiap program pengembangan organisasi dan kebijakan yang diambil. Hal ini terkait dengan bagaimana budaya itu mempengaruhi organisasi dan bagaimana suatu budaya itu dapat dikelola oleh organisasi. Budaya organisasi itu berkaitan dengan cara karyawan mempersepsikan karakteristik budaya organisasi, bukannya dengan apakah mereka menyukai budaya itu atau tidak. Artinya, budaya itu merupakan istilah deskriptif. Pemahaman ini penting karena membedakan konsep budaya dari kepuasaan kerja. Meskipun tidak diragukan kedua istilah mempunyai karakteristik yang bertumpang tindih, hendaknya diingat bahwa 
istilah budaya organisasi adalah deskriptif sedangkan kepuasaan kerja adalah evaluatif (Robbins, 2006). Berdasarkan hal tersebut maka hipotesis yang diajukan: H3: Budaya organisasi berpengaruh terhadap kepuasan kerja akuntan pendidik.

\section{Rerangka Pemikiran}

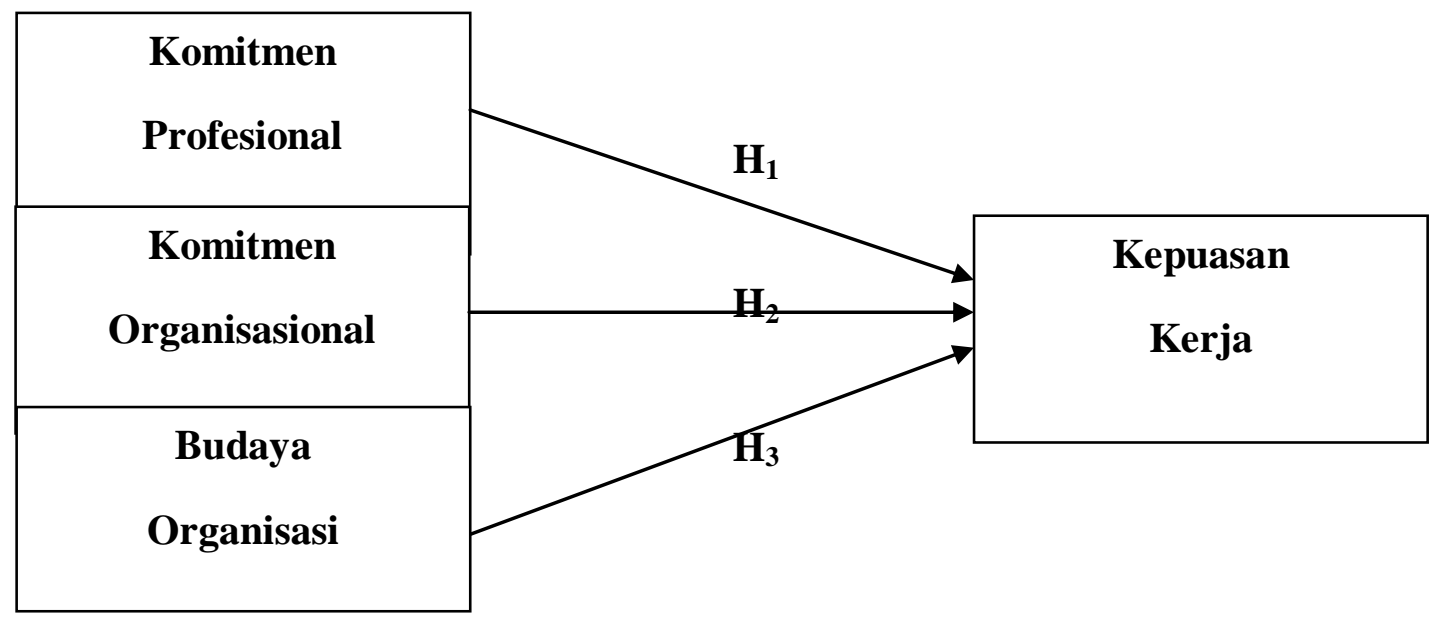

Gambar 1

Model Penelitian

\section{METODA PENELITIAN}

\section{Populasi dan Sampel Penelitian}

Populasi dalam penelitian ini adalah Akuntan Pendidik (dosen yang memiliki gelar profesi akuntan) yang ada pada Universitas di Yogyakarta. Teknik pengambilan sampel menggunakan purposive sampling untuk populasi yang telah ditentukan di atas dengan kriteria responden yaitu akuntan pendidik yang mempunyai gelar profesi akuntan atau CA dengan menggunakan kuesioner.

\section{Jenis dan Sumber Data}

Penelitian ini menggunakan data primer yaitu diperoleh dari sumber utama tanpa perantara. Sumber data diperoleh secara langsung melalui kuesioner yang diisi oleh responden akuntan pendidik. Data yang telah direspon oleh subjek penelitian, kemudian digunakan untuk analisis data. 


\section{Teknik Pengumpulan Data}

Pengumpulan data diperoleh dengan cara menyebarkan/mengirimkan daftar pertanyaan (kuesioner) secara langsung kepada para akuntan pendidik. Kuesioner merupakan teknik pengumpulan data yang dilakukan dengan cara memberikan seperangkat pertanyaan dan pertanyaan tertulis kepada responden untuk dijawab (Sugiyono, 2010). Dalam penelitian ini disebarkan 60 kuesioner kepada akuntan pendidik diberbagai universitas di Yogyakarta.

\section{Definisi Operasional dan Pengukuran Variabel}

Komitmen organisasional adalah tingkat loyalitas individu sebagai bagian dari organisasi. Hal ini direfleksikan dalam sikap individu terhadap organisasi. Komitmen organisasional diukur dengan menggunakan instrumen yang terdiri dari tiga item pertanyaan untuk komitmen organisasional negatif dan sembilan item pertanyaan untuk komitmen organisasional positif, dengan lima poin skala Likert.

Komitmen profesional adalah tingkat loyalitas individu pada profesinya seperti yang dipersepsikan oleh individu tersebut. Komitmen profesional diukur dengan menggunakan instrumen yang dikembangkan oleh Trisnaningsih (2003) digunakan pula Didit (2013), terdiri dari empat item pertanyaan negatif dan empat belas item pertanyaan positif dengan lima poin skala Likert.

Budaya organisasi adalah norma-norma dan nilai-nilai organisasi akan berperilaku sesuai dengan budaya yang berlaku agar diterima oleh lingkungannya. Budaya organisasi pada penelitian ini diukur dengan menggunakan instrumen yang digunakan oleh Wulansari (2012) yang terdiri dari sepuluh instrumen dengan lima point skala Likert.

Kepuasan Kerja adalah tingkat kepuasan individu dengan posisinya dalam organisasi secara relatif dibandingkan dengan teman sekerja lain. Kepuasan kerja pada penelitian ini diukur dengan menggunakan instrumen yang dikembangkan oleh Didit (2013), terdiri dari sepuluh instrumen dengan lima poin skala Likert. 


\section{TEKNIK ANALISIS DATA}

\section{Statistik Deskriptif}

Statistik deskriptif digunakan untuk penggambaran atau pendeskripsian data. Statistik deskriptif memberikan gambaran atau deskriptif suatu data yang dilihat dari nilai rata-rata, deviasi standar, nilai minimum dan maksimum, serta range (Ghozali, 2011: 19).

\section{Uji Kualitas Data}

Penelitian ini menggunakan data primer berupa kuesioner, sehingga diperlukan uji kualitas data yang terdiri atas uji validitas data dan reliabilitas data. Uji Validitas digunakan untuk mengukur sah atau tidaknya suatu instrumen penelitian, dalam hal ini yaitu kuesioner. Suatu kuesioner dinyatakan valid jika pertanyaan pada kuesioner mampu mengungkapan sesuatu yang akan diukur oleh kuesioner tersebut. Sementara itu, uji reliabilitas bertujuan untuk menunjukan sejauh mana suatu hasil pengukuran relatif konsisten apabila pengukuran diulangi dua kali atau lebih.

\section{Analisis Regresi Berganda}

Pengujian ini dilakukan setelah data dikumpulkan dengan menggunakan regresi linier berganda yaitu analisis digunakan untuk mengetahui apakah ada pengaruh dari komitmen profesional, komitmen organisasional dan budaya organisasi terhadap kepuasaan kerja akuntan pendidik, dengan rumus:

\section{$Y=a+b 1 X 1+b 2 X 2+b 3 X 3+e i$}

Keterangan :

$\begin{array}{ll}\mathrm{Y} & =\text { Kepuasaan Kerja Akuntan Pendidik } \\ \mathrm{a} & =\text { Bilangan Konstanta } \\ \mathrm{b} 1, \mathrm{~b} 2, \mathrm{~b} 3 & =\text { Koefisien Regresi } \\ \mathrm{X} 1 & =\text { Komitmen Profesional } \\ \mathrm{X} 2 & =\text { Komitmen Organisasional } \\ \mathrm{X} 3 & =\text { Budaya Organisasi } \\ \mathrm{ei} & =\text { Error }\end{array}$




\section{Uji Asumsi Klasik}

1. Uji Normalitas

Tujuan uji normalitas adalah untuk menguji dalam sebuah model regresi, variabel terikat dan variabel bebas atau keduanya mempunyai distribusi normal ataukah tidak. Dasar pengambilan keputusan dari uji normalitas adalah dengan melihat probabilitas asymp.sig (2-tailed) > 0,05 maka data mempunyai distribusi normal dan sebaliknya (Ghozali, 2011: 160).

\section{Uji Heteroskedastisitas}

Uji heteroskedastisitas bertujuan untuk menguji ada atau tidaknya kesamaan varian dari residual satu pengamatan ke pengamatan lain dalam model regresi. Uji statistik yang digunakanan dalam penelitian ini untuk mengetahui ada tidaknya heteroskedatisitas yaitu uji Glejser. Jika nilai signifikansi di atas nilai alpha $(0,05)$ maka model regresi tidak mengandung adanya heteroskedastisitas (Ghozali, 2011: 139).

\section{Uji Multikolinieritas}

Uji multikolinieritas dilakukan untuk menguji pada model regresi ditemukan adanya korelasi antar variabel bebas. Kemungkinan terjadinya multikolinieritas dapat dilihat dari nilai tolerance dan variance inflation factor (VIF). Dasar pengambilan keputusan adalah apabila nilai tolerance $>0,1$ atau sama dengan nilai VIF $<10$ berarti tidak ada multikolinearitas antar variabel dalam regresi (Ghozali, 2011: 105).

\section{Uji Hipotesis}

1. Pengujian koefisien determinasi $\left(\mathrm{R}^{2}\right)$

Pengujian koefisien determinasi $\left(\mathrm{R}^{2}\right)$ bertujuan mengukur kemampuan model dalam menerangkan variasi variabel dependen. Nilai koefisien determinasi adalah antara nol dan satu. Nilai $\mathrm{R}^{2}$ yang kecil berarti bahwa kemampuan variabel-variabel independen dalam menjelaskan variasi variabel dependen amat terbatas. Begitupula sebaliknya, nilai yang mendekati satu berarti bahwa hampir semua informasi yang dibutuhkan untuk memprediksi variasi variabel dependen (terikat).

2. Uji F

Uji F digunakan untuk membuktikan secara statistik koefisien regresi juga signifikan. Menggunakan level of significance $(\alpha)=0,05$, maka kriteria ada tidaknya 
pengaruh antara variabel bebas dengan variabel terikat secara simultan. Jika nilai signifikansi $<0,05$, maka semua variabel independen secara simultan merupakan penjelas variabel dependen. Jika nilai signifikansi $>0,05$, maka semua variabel independen secara simultan bukan merupakan penjelas variabel dependen.

\section{Uji Statistik t}

Uji statistik t ini pada dasarnya menunjukkan pengaruh variabel independen secara individual dalam menerangkan variasi variabel dependen. Uji t digunakan untuk menguji hipotesis 1 sampai 3 pada penelitian ini. Dasar pengambilan keputusan pada uji t ini adalah dengan melihat nilai probabilitas signifikansi. Jika nilai probabilitas signifikansi < tingkat kepercayaan $(0,05)$, maka variabel independen secara individu mempengaruhi variabel dependen. Sebaliknya jika nilai probabilitas signifikansi > tingkat kepercayaan $(0,05)$, maka variabel independen secara individu tidak mempengaruhi variabel dependen (Ghozali, 2006: 88-91).

\section{HASIL DAN PEMBAHASAN}

\section{Uji Statistik Deskriptif}

Tabel 1

Hasil Statistik Deskriptif

\begin{tabular}{|l|c|c|c|c|c|c|c|}
\hline & N & Min & Max & Sum & Mean & $\begin{array}{c}\text { Std. } \\
\text { Deviation }\end{array}$ & Variance \\
\hline $\begin{array}{l}\text { Komitmen } \\
\text { Professional }\end{array}$ & 45 & 46 & 76 & 2832 & 62.93 & 7.111 & 50.564 \\
\hline $\begin{array}{l}\text { Komitmen } \\
\text { Organisasional }\end{array}$ & 45 & 24 & 57 & 2110 & 46.89 & 6.050 & 36.601 \\
\hline $\begin{array}{l}\text { Budaya } \\
\text { Organisasi }\end{array}$ & 45 & 30 & 46 & 1794 & 39.87 & 3.782 & 14.300 \\
\hline $\begin{array}{l}\text { Kepuasaan } \\
\text { Kerja }\end{array}$ & 45 & 30 & 47 & 1765 & 39.22 & 3.655 & 13.359 \\
\hline
\end{tabular}

Sumber : Data primer, Diolah (2015)

Tabel 1 menunjukkan bahwa jumlah responden 45, dari 45 responden ini komitmen profesional terkecil (minimum) adalah 46 dan terbesar (maximum) adalah 76. Rata-rata komitmen profesional adalah 62,93 dengan standar deviasi 7,111. Nilai variance sebesar 50,564. Sementara itu variabel komitmen organisasional data terkecil adalah 24 dan terbesar adalah 57. Rata-rata komitmen organisasional 46,89 dengan standar deviasi 6,050. 
Budaya organisasi nilai terkecil adalah 30 dan terbesar adalah 46. Rata-rata komitmen organisasional 39,87 dengan standar deviasi 3,782. Nilai variance menunjuukkan angka 14,300. Kepuasaan kerja terkecil adalah 30 dan terbesar adalah 47. Rata-rata komitmen organisasional 39,22 dengan standar deviasi 3,655.. Nilai variance menunjukkan angka 13,359.

\section{Uji Kualitas Data}

Uji kualitas data yang pertama dilakukan yaitu pengujian validitas instrumen. Peneliti melakukan perhitungan dengan membandingkan $r$ tabel terhadap $r$ hitung untuk df $=\mathrm{n}-2$, dalam hal ini $\mathrm{n}$ adalah jumlah sampel. Penelitian ini memiliki jumlah sampel $(n)=45$ dan besarnya df dapat dihitung 45-2=43, dengan $\mathrm{df}=43$ dan alpha= 0,05 didapat $r$ tabel 0,2940 . Jika $r$ hitung lebih besar dari $r$ tabel dengan nilai positif maka item pertanyaan tersebut dinyatakan valid dan sebaliknya. Pada hasil uji kualitas data diketahui bahwa semua item valid.

Uji kualitas data selanjutnya adalah reliabilitas yang digunakan untuk menguji kehandalan suatu alat pengukur yang dapat digunakan kembali untuk penelitian yang sama. Pengujian reliabilitas dalam penelitian ini menggunakan teknik cronbach's alpha. Penelitian ini memiliki hasil yang cronbach alpha lebih besar dari 0,60 sehingga dapat dikatakan bahwa semua item instrumen dalam penelitian ini reliabel.

\section{Analisis Regresi Berganda}

\section{Uji Asumsi Klasik}

1. Uji Normalitas

Tabel 2

Hasil Uji Normalitas

\begin{tabular}{|c|c|c|}
\hline Keterangan & Unstandardized Residual & Alpha \\
\hline $\mathrm{N}$ & 45 & \multirow{2}{*}{0,05} \\
\hline asymp.Sig. (2-tailed) & 0,942 & \\
\hline
\end{tabular}

Sumber : Data primer, Diolah (2015) 
Hasil uji normalitas pada tabel 2 menunjukkan bahwa besarnya nilai asymp. Sig. (2-tailed) adalah 0,942 lebih besar dari nilai alpha (0,05). Artinya, bahwa data residual terdistribusi secara normal.

2. Uji Heteroskedastisitas

Tabel 3

Hasil Uji Heteroskedatisitas

\begin{tabular}{|l|c|c|}
\hline \multicolumn{1}{|c|}{ Keterangan } & Signifikansi & Alpha \\
\hline Komitmen Professional & 1,000 & 0,05 \\
\hline Komitmen Organisasional & 1,000 & 0,05 \\
\hline Budaya Organisasi & 1,000 & 0,05 \\
\hline
\end{tabular}

Sumber : Data primer, Diolah (2015)

Berdasarkan hasil yang ditunjukan oleh tabel 3 nilai signifikansi untuk variabel independen lebih besar dari nilai alpha $(0,05)$. Artinya, model regresi tidak terdapat heteroskedastisitas.

3. Uji Multikolinearitas

Tabel 4

Hasil Uji Multikolinearitas

\begin{tabular}{|l|c|c|}
\hline \multicolumn{1}{|c|}{ Variabel } & Tolerance & VIF \\
\hline Komitmen Professional & 0,495 & 2,019 \\
\hline Komitmen Organisasional & 0,342 & 2,925 \\
\hline Budaya Organisasi & 0,352 & 2,842 \\
\hline
\end{tabular}

Sumber : Data primer, Diolah (2015)

Berdasarkan hasil yang ditunjukkan oleh tabel 4, nilai tolerance pada masingmasing variabel independen $>0,1$ dan nilai variance inflation factor $(V I F)<10$. Artinya dapat diketahui bahwa dalam model regresi tidak terdapat multikolinearitas. 


\section{Uji Hipotesis}

Tabel 5

Hasil Analisis Regresi Linear Berganda

\begin{tabular}{|c|c|c|c|c|}
\hline \multirow{2}{*}{ Model } & \multicolumn{2}{|c|}{$\begin{array}{c}\text { Unstandardized } \\
\text { Coefficients }\end{array}$} & \multirow{2}{*}{ Sig. } \\
\cline { 2 - 3 } & Koefisien & Std. Error & & \\
\hline Konstanta & 7,222 & 3.619 & 1.995 & 0,053 \\
\hline X1 & 0.097 & 0.066 & 1.472 & 0,149 \\
\hline X2 & 0.046 & 0.093 & 0.492 & 0,625 \\
\hline X3 & 0.596 & 0.147 & 4.07 & 0,000 \\
\hline F hitung & 27,563 & & \\
\hline Sig. F & 0,000 & & \\
\hline Adjusted $\mathrm{R}^{2}$ & 0,644 & & \\
\hline Sumb : Datang & & \\
\hline
\end{tabular}

Sumber : Data primer, Diolah (2015)

1. Koefisien Determinasi $\left(\mathrm{R}^{2}\right)$

Berdasarkan tabel 5 nilai adjusted $\mathrm{R}^{2}$ sebesar 0,644. Hal ini berarti 64,4\% variabel dependen (kepuasan kerja akuntan pendidik) dapat dijelaskan oleh ketiga variabel independen yaitu komitmen profesional, komitmen organisasional dan budaya organisasi. Sedangkan sisanya $(100 \%-64,4 \%=35,6 \%)$ dijelaskan oleh faktor-faktor lain di luar model yang diteliti dalam penelitian ini.

\section{Uji F}

Berdasarkan tabel 4.15 hasil perhitungan statistik $\mathrm{F}$ sebesar 27,563 dengan nilai signifikansi 0,000 . Signifikansi jauh lebih kecil dari 0,05 yang berarti secara simultan seluruh variabel independen berpengaruh secara signifikansi terhadap variabel dependen. Model regresi ini dapat menjelaskan bahwa komitmen profesional, komitmen organisasional dan budaya organisasi secara bersama-sama berpengaruh terhadap kepuasaan kerja akuntan pendidik.

\section{Uji t}

a. Komitmen Profesional terhadap Kepuasan Kerja Akuntan Pendidik.

Hasil dari analisis regresi menunjukkan nilai koefisien regresi 0,097 dengan nilai signifikansi 0,149. Karena nilai signifikansi lebih besar dari nilai alpha $(0,05)$, maka hipotesis pertama dalam penelitian ini ditolak. Jadi komitmen profesional tidak berpengaruh terhadap kepuasan kerja akuntan pendidik. Penurunan komitmen 
professional akan diikuti dengan menurunnya kepuasan kerja Akuntan Pendidik. Keputusan ini tidak konsisten dengan keputusan yang dilakukan oleh Restuningdiah (2009) yang menyatakan bahwa adanya pengaruh komitmen profesional terhadap kepuasan kerja akuntan pendidik.

b. Komitmen Organisasional terhadap Kepuasan Kerja Akuntan Pendidik.

Hasil dari analisis regresi menunjukkan nilai koefisien regresi 0,046 dengan nilai signifikansi 0,625. Karena nilai signifikansi lebih besar dari nilai alpha $(0,05)$, maka hipotesis kedua dalam penelitian ini ditolak. Jadi komitmen organisasional tidak berpengaruh terhadap kepuasan kerja Akuntan Pendidik. Penurunan komitmen organisasional akan diikuti dengan menurunnya kepuasan kerja Akuntan Pendidik. Keputusaan ini tidak konsisten dengan keputusaan yang dilakukan oleh Restuningdiah (2009) yang menyatakan bahwa adanya pengaruh komitmen organisasional terhadap kepuasan kerja Akuntan Pendidik.

c. Budaya Organisasi terhadap Kepuasan Kerja Akuntan Pendidik.

Hasil dari analisis regresi menunjukkan nilai koefisien regresi 0,596 dengan nilai signifikansi 0,000. Karena nilai signifikansi lebih kecil dari nilai alpha $(0,05)$, maka hipotesis ketiga dalam penelitian ini diterima. Jadi budaya organisasi berpengaruh terhadap kepuasan kerja akuntan pendidik. Peningkatan budaya organisasi akan diikuti dengan meningkatnya kepuasan kerja, dan begitupula sebaliknya.

\section{SIMPULAN, KETERBATASAN, DAN SARAN}

Berdasarkan analisis data yang telah diuraikan sebelumnya, maka dapat ditarik simpulan sebagai berikut:

1. Komitmen Profesional tidak berpengaruh terhadap kepuasan kerja akuntan pendidik.

2. Komitmen organisasional tidak berpengaruh terhadap kepuasan kerja akuntan pendidik

3. Budaya Organisasi berpengaruh terhadap kepuasan kerja akuntan pendidik.

Beberapa saran yang perlu dipertimbangkan untuk diterapkan pada penelitian selanjutnya adalah sebagi berikut. 
1. Teknik pengumpulan data tidak hanya dilakukan dengan penyebaran kuesioner, sebaiknya peneliti selanjutnya mengumpulkan data dengan melakukan teknik wawancara secara langsung, sehingga dapat memperoleh informasi yang lebih lengkap.

2. Memperluas sampel yang diteliti, dengan menambah sampel penelitian perguruan tinggi yang berada di Indonesia agar hasil penelitian dapat lebih digeneralisir.

Beberapa saran yang perlu dipertimbangkan untuk diterapkan pada penelitian selanjutnya adalah sebagi berikut

1. Teknik pengumpulan data tidak hanya dilakukan dengan penyebaran kuesioner, sebaiknya peneliti selanjutnya mengumpulkan data dengan melakukan teknik wawancara secara langsung, sehingga dapat memperoleh informasi yang lebih lengkap.

2. Memperluas sampel yang diteliti, dengan menambah sampel penelitian perguruan tinggi yang berada di Indonesia agar hasil penelitian dapat lebih digeneralisir.

\section{DAFTAR PUSTAKA}

Aranya, N., and Ferris. 1983. Organizational - professional Conflict among US and Israeli Professional Accountants Journal of Social Psychology, vol. 119. 153161.

Cahyono, D., and Ghozali, I. 2002. Pengaruh Jabatan, Budaya Organisasional dan Konflik Peran terhadap Hubungan Kepuasan Kerja dengan Komitmen Organisasi : Studi Empiris di Kantor Akuntan Publik, Jurnal Riset Akuntansi Indonesia,.Vol. 5. No. 3, September 2002, 341-364.

Detriyanto, Didit. 2013. Pengaruh Komitmen Organisasional Komitmen Professional dan Motivasi Terhadap Kepuasaan Kerja Auditor. Skripsi. Universitas Ahmad Dahlan.

Dewi, Rosita Amilin. 2008. Pengaruh Komitmen Organisasi Terhadap Kepuasaan Kerja Akuntan Dengan Role Stress Sebagai Variabel Moderating. Jurnal Riset. UIN Syarif Hidayatullah. Jakarta.

Ghozali, imam. 2006. Aplikasi Analisis Multivariate dengan Program SPSS. Semarang : BP UNDIP. 
http://zhes.wordpress.com/2011/01/15/akuntan-pendidik/. 20 Oktober 2014.

http://dhino-ambargo.blogspot.com/2013/05/pengertian-dan-fungsi-budayaorganisasi.html. 04 November 2014.

http://chalouiss.blogspot.com/2012/09/profesi-akuntan.html. 21 Desember 2014.

Ismawati, Dwi. 2014. Pengaruh Komitmen Organisasi Pengendalian Internal dan Akuntabilitas Publik Terhadap Kinerja Organisasi. Skripsi. Universitas Ahmad Dahlan.

Kurniawati, Indah. 2006. Pengolahan Data Elektronik.Universitas Ahmad Dahlan.

Kusuma, Putra Randy. 2014. "Pengaruh Motivasi, Kepemimpinan Serta Budaya Organisasi Terhadap Kepuasaan Kerja Karyawan Non Akademik di Universitas Ahmad Dahlan”. Skripsi S-1 Yogyakarta : Universitas Ahmad Dahlan.

Luthans, F. 2005. Perilaku Organisasi. Edisi 10. Yogyakarta: Andi.

Restuningdiah, Nurika. 2009. Pengaruh Komitmen Profesional terhadap Kepuasaan Kerja melalui Komitmen Organisasional (Studi Empiris pada Akuntan Pendidik di JawaTimur).Jurnal Ekonomi Bisnis, Thn 14, No 3. Universitas Negeri Malang. Surabaya.

Robbins, Stephen P. 2008. Perilaku Organisasi: Organization Behavior. Jilid 1.Edisi 12. Jakarta: Salemba Empat.

Robbins, Stephen P. 2006. Perilaku Organisasi. Edisi10. Jakarta : PT. Macaman Jaya Cemerlang.

Setyorini, Christina Tri.dkk. 2012. "Pengaruh Komitmen Organisasi, Budaya Organisasi, dan Keterlibatan Kerja Terhadap kinerja Karyawan Baitul Maal Wat Tamwil (BMT)". Media Riset Akuntansi Vol 2 No. 1 Februari 2012.

Sobirin, Achmad. 2009. Budaya Organisasi. Edisi kedua. Yogyakarta: UPP STIM YKPN.

Sugiyono. 2009. Metode Penelitian Bisnis. Bandung. . CV Alfabeta

Trisnaningsih, S. 2003. Pengaruh Komitmen terhadap Kepuasan Kerja Auditor: Motivasi sebagai Variabel Intervening (Studi Empiris pada Kantor Akuntan Publik di Jawa Timur). Jurnal Riset Akuntansi Indonesia, Vol 6, No.2, Mei, 199-216. 
Trisnaningsih, Sri. dan Didik Adiyanto. 2002. Pengaruh Komitmen terhadap Kepuasaan Kerja Auditor: Motivasi sebagai Variabel Intervening. Simposium Nasional Akuntansi 5 (September).

Wulansari, Indriani. 2012."Pengaruh independensi auditor, komitmen organisasi, gaya kepemimpinan, budaya organisasi, dan pemahaman Good Governance terhadap kinerja auditor". Skripsi S-1 Yogyakarta : Universitas Ahmad Dahlan

Yahya, Murip. Profesi Tenaga Kependidikan. Bandung: Pustaka Setia 